\title{
PERUBAHAN TINGKAT FATIGUE MELALUI LATIHAN PROGRESSIVE MUSCLE RELAXATION (PMR) PADA PASIEN GAGAL GINJAL KRONIS YANG MENJALANI HEMODIALISA
}

\author{
Santi Herlina ${ }^{1}$, Ratna Sitorus ${ }^{2}$, Masfuri ${ }^{3}$
}

1. Program Studi Ilmu Keperawatan, Fakultas Ilmu - Ilmu Kesehatan, Universitas Pembangunan Nasional "Veteran", Jakarta 12450, Indonesia

2. Keperawatan Medikal Bedah, Fakultas Ilmu Keperawatan, Universitas Indonesia, Depok 16424, Indonesia

3. Keperawatan Medikal Bedah, Fakultas Ilmu Keperawatan, Universitas Indonesia, Depok 16424, Indonesia

\section{E-mail : $\underline{\text { alfarabialbi@yahoo.co.id }}$}

\section{Abstrak}

Fatigue merupakan keluhan utama pasien yang menjalani hemodialisa jangka panjang, yang memiliki nilai yang tinggi, sehingga akan mempengaruhi kualitas hidup pasien. Tujuan dari penelitian ini adalah mengetahui pengaruh PMR terhadap tingkat fatigue pada pasien gagal ginjal kronis yang menjalani hemodialisa. Penelitian ini menggunakan desain quasi experiment pendekatan pretest-posttest control group. Jumlah responden dalam penelitian adalah 32 pasien dibagi 2 kelompok yaitu 16 kelompok intervensi dan 16 kelompok kontrol. Hasil penelitian menyimpulkan bahwa terdapat perbedaan yang signifikan terhadap tingkat fatigue pada kelompok intervensi antara sebelum dan sesudah dilakukan PMR dengan nilai $p=0,000$. Disarankan latihan PMR dapat digunakan sebagai intervensi keperawatan mandiri dalam menurunkan fatigue pada pasien gagal ginjal kronis yang menjalani hemodialisa.

Kata kunci: Fatigue, Pasien gagal ginjal kronik, Hemodialisis, PMR, Intervensi keperawatan

\section{Abstract}

Fatigue is a major complaint of patients undergoing long-term hemodialysis, which has a high value, so it will affect the quality of life of patients. The purpose of this study was to determine the influence of PMR on the level of fatigue in patients with chronic kidney disease undergoing hemodialysis. This study used a quasi experiment design approach pretest-posttest control group. The number of respondents in the study were 32 patients divided into 2 groups: the 16 intervention group and 16 control group. The research concludes that there are significant differences on the level of fatigue in the intervention group between before and after PMR with $p=0.000$. Suggested training PMR can be used as an independent nursing intervention in reducing fatigue in patients with chronic kidney disease undergoing hemodialysis.

Keywords : Fatigue, Chronic kidney disease patients, Hemodialysis, PMR, Nursing Intervention 


\section{Pendahuluan}

Menurut data profil kesehatan Indonesia (2006) gagal ginjal menempati urutan ke-6 sebagai penyebab kematian pasien yang dirawat diseluruh Indonesia dengan angka kejadian 2,99\%, sedangkan menurut Perhimpunan Nefrologi Indonesia (PERNEFRI) penderita gagal ginjal kronis mencapai 70.000 orang dengan keseluruhan membutuhkan hemodialisis.

Bagi pasien gagal ginjal kronis, hemodialisa merupakan salah satu pilihan untuk bisa memperpanjang usia hidupnya. Namun demikian, hemodialisa tidak menyembuhkan atau memulihkan penyakit ginjal dan tidak mampu mengimbangi hilangnya aktivitas metabolik atau endokrin yang dilaksanakan ginjal dan dampak dari gagal ginjal serta terapinya terhadap kualitas hidup pasien. (Smeltzer \& Bare, 2002).

Salah satu gejala yang paling umum pada pasien yang menjalani dialisa adalah keletihan (fatigue). Fatigue merupakan keluhan utama pasien yang menjalani hemodialisis jangka panjang. Prevelensi dari keletihan berkisar $60 \quad \% \quad$ sampai $\quad 97 \%$
(Murtaugh, Addington

\&

Higginson,2007; Weisbord et al.,2005).

Fatigue menurut NANDA (2009) adalah rasa letih luar biasa dan penurunan kapasitas kerja fisik dan jiwa pada tingkat yang biasanya secara terus menerus. Ménurut Polaschek (2003) salah satu pengalaman orang yang menerima hemodialisa, gejala yang tidak diinginkan adalah fatigue sebagai gejala yang paling menganggu, dan fatigue telah dilaporkan sebagai gejala yang paling umum di kalangan pasien hemodialisis (Jablonski, 2007).

Peran perawat dalam mengatasi fatigue adalah dengan dimulai dari awal pengkajian dengan cermat mengenai tingkat fatigue setiap pasien dan jumlah aktivitas yang dilakukan sampai menyusun intervensi yang tepat bagi setiap pasien, sehingga harapan dari ini semua kualitas hidup pasien penyakit ginjal kronis yang menjalani hemodialisa dapat meningkat. Tidak semua pasien hemodialisa mengalami fatigue yang sama dan fatigue merupakan pengalaman individual. 
Dalam penelitian Kwekkeboom, Anderson, Wanta (2010), intervensi perilaku kognitif yang terdiri dari progressive muscle relaxation, distraksi dan guide imagery dapat diterapkan untuk mengatasi fatigue pada pasien kanker, dimana hasilnya rata-rata nilai fatigue mengalami penurunan dari sebelum diterapi dan setelah diterapi.

Melihat fenomena diatas peneliti tertarik untuk melakukan penelitian " Pengaruh progressive muscle relaxation $(P M R)$ terhadap tingkat fatigue pada pasien gagal ginjal kronis yang menjalani hemodialisa"

\section{Metode Penelitian}

Penelitian ini menggunakan desain quasi experiment nonequivalent control group design atau pretestposttest control group design dimana pada kelompok perlakuan maupun kelompok kontrol tidak dipilih secara random. Analisis data dilakukan secara univariat dan bivariat yaitu dengan mean, frekuensi dan uji $\mathrm{t}$ independent dan $\mathrm{t}$ dependent.

Alat pengumpul data adalah kuesinoer skala fatigue Piper Fatigue
Scale yang terdiri dari 14 pertanyaan dengan skor nilai 1- 10. Pengukuran dilakukan dua kali, pada awal sebelum intervensi dan diukur kembali setelah dilakukan $5 \times$ latihan PMR.

\section{Hasil Penelitian}

\section{A. Pengaruh PMR terhadap tingkat fatigue}

Hasil penelitian ini menunjukkan bahwa pasien gagal ginjal kronis yang menjalani hemodialisa yang dengan pemberian intervensi $P M R$ selama 5 kali latihan dengan durasi \pm 25 menit memperlihatkan adanya perbedaan rata-rata tingkat fatigue dari sebelum dan sesudah diberikan intervensi, yaitu mengalami penurunan tingkat fatigue dari rata-rata nilai fatigue sebelum intervensi yaitu 6,03 yang merupakan kategori fatigue sedang menjadi 2,51 setelah intervensi yang merupakan kategori fatigue ringan. Sehingga hasil penelitian ini dapat disimpulkan terdapat pengaruh yang signifikan pemberian latihan $P M R$ terhadap penurunan tingkat fatigue pada pasien gagal ginjal kronis yang menjalani hemodialisa. 
Hasil penelitian ini sejalan dengan penelitian yang dilakukan oleh Kwekkeboom, Kristine et al, 2010 tentang kombinasi intervensi $P M R$, distraksi dan imagery terhadap fatigue pada pasien kanker yang menghasilkan rata - rata nilai fatigue mengalami penurunan dari sebelum diterapi dan setelah diterapi. Fatigue merupakan keluhan utama pasien yang menjalani hemodialisis jangka panjang. Prevelensi dari keletihan berkisar $60 \quad \%$ sampai $97 \%$ (Murtaugh, Addington \& Higginson, 2007; Weisbord et al., 2005). Fatigue yang terjadi pada pasien gagal ginjal kronis yang menjalani hemodialisa dipengaruhi oleh beberapa faktor salah satunya adalah faktor psikologis yang terdiri dari stress, depresi, ansietas dan gangguan pola tidur (Welch, 2006 \& Jhamb, Weisbord, Stell, Unruh, 2008). Pada penelitian McCann dan Boore (2000) ditemukan hubungan yang signifikan antara fatigue dengan gangguan pola tidur, depresi, cemas dan kemampuan fisik yang menurun. Selain itu terdapat beberapa faktor yang lain yaitu faktor fisiologi yang terdiri dari anemia, malnutrisi, uremia, hiperparatiroid dan inflamasi. dan faktor sosiodemografi terdiri dari usia, jenis kelamin, pendidikan, status pekerjaan, status marital dan dukungan sosial.

Progressive muscle relaxation adalah salah satu teknik yang khusus didesain untuk membantu meredakan ketegangan otot yang terjadi ketika sadar, pertama pasien harus mengetahui derajat ketegangan otot dan mengurangi derajat ketegangan otot dengan teknik pelepasan ketegangan (National Safety Council, 2003). $P M R$ yang merupakan salah satu bagian dari Nursing Intervention Classsification (NIC) yang berada pada level 1 domain basic : physiological dengan kelas physical comfort promotion ( Bulecheck, Butcher, Dochterman, 2008) memiliki peran dalam menurunkan fatigue pada pasien gagal ginjal kronis yang menjalani hemodialisa dikaitkan dengan faktor psikologis yaitu depresi dan cemas yang pemicunya adalah stress. Pasien yang menjalani dialisa menjadi stress akibat selama hidupnya harus tergantung terhadap terapi ini, penatalaksanaan regimen yang sangat ketat mulai dari makanan, 
pembatasan cairan dan pengobatan, bahkan dapat terancam hidupnya sewaktu-waktu terhadap penyakit yang dialaminya.

Progressive muscle relaxation untuk mengatasi fatigue pada pasien gagal ginjal kronis dikaitkan dengan faktor psikologis yaitu depresi dan cemas yang pemicunya adalah stres. Respon stress masuk kedalam sistem saraf pusat, lalu dihipotalamus dilepaskan corticotrophin releasing factor yang akan menstimulasi sistem saraf simpatis untuk mengeluarkan norepinefrin yang merupakan vasokonstriktor dan berakibat pada kontraksi otot polos (Guyton \& Fall, 2007). Pemberian latihan $P M R$ untuk menurunkan gejala fatigue adalah dengan cara PMR menghambat jalur diatas dengan mengaktivasi kerja sistem saraf parasimpatis dan memanipulasi hipotalamus melalui pemusatan pikiran untuk memperkuat sikap positif sehingga rangsangan stres terhadap hipotalamus berkurang. (Copstead\&Banasik, 2000). Selain itu pemberian $P M R$ memberikan efek relaksasi otot sehingga terjadi vasodilatasi pembuluh darah yang memberikan efek tenang dan nyaman.
Pemberian PMR pada klien yang mengalami gangguan pola tidur dapat menurunkan ketegangan fisiologis, meningkatkan relaksasi otot, menurunkan kecemasan sehingga terjadi vasodilatasi pembuluh darah. Aliran darah sistemik menjadi lancar, denyut nadi menjadi normal, frekwensi pernapasan menjadi normal dan mengurangi evaporasi sehingga klien menjadi nyaman dan pikiran menjadi tenang, sebagai akibat dari penurunan aktivasi reticular activating system (ras) dan peningkatan aktivitas batang otak, sehingga hal ini dapat mengurangi gejala fatigue.

Pada penelitian Vancamport et al (2011) PMR efektif untuk menurunkan kecemasan, stress psikologis dan fatigue pada pasien schizophrenia, begitu pula penelitian Yilidirim \& Fadiloglu (2006) menyebutkan bahwa PMR menurunkan kecemasan dengan nilai $p<0,001$ dan meningkatkan kualitas hidup pasien yang menjalani dialisa dengan nilai $p<0,01$.

Manfaat dari PMR adalah untuk mengatasi berbagai macam permasalahan dalam mengatasi stres, 
kecemasan, insomnia, dan juga dapat membangun emosi positif dari emosi negatif. Keempat permasalahan tersebut dapat menjadi suatu rangkaian bentuk gangguan psikologis bila tidak diatasi. Stres terhadap tugas maupun permasalahan lainnya, yang tidak segera diatasi dapat memunculkan suatu bentuk kecemasan dalam diri seseorang. Kecemasan itu sendiri bila tidak juga diatasi dapat berakibat pada munculnya emosi negatif baik terhadap permasalah yang timbul akibat stres juga perilaku sehari-hari seseorang dan relaksasi bisa digunakan agar seseorang kembali pada taraf keadaan normal.

\section{B. Pengaruh variabel confounding} terhadap tingkat fatigue

\section{Hubungan usia dengan tingkat} fatigue

Dari hasil penelitian ini diketahui bahwa usia memilki hubungan yang sedang dan berpola positif dengan hasil tidak ada hubungan yang bermakna antara usia dengan tingkat fatigue dengan nilai $\mathrm{P}$ Value 0,142 pada kelompok intervensi begitu juga dengan kelompok kontrol tidak ada hubungan yang bermakna antara usia dengan fatigue dengan nilai $\mathrm{P}$ Value 0,758. Hal ini sejalan dengan penelitian Sulistini disimpulkan bahwa usia memiliki hubungan yang negative dan tidak terdapat hubungan yang signifikan antara usia dengan fatigue. Penelitian O'Sullivan dan McCarthy (2007) bahwa usia memiliki hubungan positif akan tetapi hasilnya tidak signifikan dengan fatigue. Hal ini mengindikasikan usia hanya menjadi trend atau kecenderungan, jika usia lebih tua maka tingkat fatiguenya cenderung meningkat. Perubahan fisiologis yang terjadi pada usia tua juga memungkinkan pasien yang lebih tua mudah mengalami fatigue (Jhamb, 2008; Mollaoglu, 2009). Seperti halnya pada penelitian Liu, 2006 menunjukkan hubungan nilai yang lemah $(0,24)$ dan berpola positif bahwa responden yang lebih tua akan mengalami fatigue dibandingkan responden yang lebih muda.

\section{Hubungan jenis kelamin dengan tingkat fatigue}

Pada penelitian ini dihasilkan bahwa tidak ada hubungan yang bermakna antara jenis kelamin dengan tingkat 
fatigue dengan nilai $p$ 0,35. Hal ini sejalan dengan penelitian pada Sulistini (2010) bahwa tidak ada hubungan yang bermakna antara jenis kelamin dengan fatigue. Menurut penelitian Nijrolder et al (2009) Jenis kelamin perempuan lebih lebih banyak mengalami fatigue $(73,9 \%)$ dibandingkan laki-laki, hal ini dikarenakan perempuan lebih mudah untuk membicarakan masalahnya dibandingkan laki-laki yang memiliki sifat tertutup untuk menceritakan keluhan yang dirasakan (Mollaoglu, 2009; Liu, 2006). Hal ini sejalan dengan penelitian O'Sullivan dan Mc Charthy (2010) bahwa perempuan lebih fatigue daripada laki-laki. Responden pada penelitian ini adalah 68,8\% laki-laki yang memiliki sifat tertutup untuk menceritakan keluhan yang dirasakan. Selain itu, menurut Guyton \& Hall (2007), menyebutkan bahwa pada laki-laki pengaruh testosterone sangat berperan penting pada perkembangan otot. Testosteron yang disekresi oleh testis memiliki efek anabolik yang kuat terhadap penyimpanan protein yang sangat besar disetiap tempat dalam tubuh, namun terutama didalam otot. Ratarata $50 \%$ masa otot laki-laki meningkat melebihi masa otot perempuan. Karena pengaruh testosteron yang sangat besar pada otot tubuh, sehingga hormon ini berfungsi untuk meningkatkan kekuatan dan tenaga otot. Sehingga dengan melihat mekanisme diatas disimpulkan perempuan akan lebih mudah fatigue dibandingkan dengan laki-laki.

\section{Hubungan pendidikan dengan} tingkat fatigue

Pada penelitian ini dihasilkan bahwa tidak ada perbedaan fatigue diantara kelima jenjang pendidikan, dengan masing-masing nilai $p$ pada kelompok intervensi 0,146 dan kelompok kontrol 0,782. Hal ini sejalan dengan penelitian Liu (2006) yang menunjukkan bahwa hasil analisis uji Scheffe's $(2,45)$, tidak ada perbedaan fatigue diantara jenjang pendidikan. Rata - rata pendidikan pasien pada penelitian ini adalah SMA yang merupakan kategori pendidikan tinggi yang dimungkinkan kurang serius menanggapi keluhan fatigue akibat proses penyakit yang berkepanjangan. Menurut Mollaouglu (2009) pendidikan yang tinggi mengakibatkan orang dapat 
mengelola fatigue dengan baik dibandingkan dengan yang berpendidikan rendah. Pengalaman dan pemahaman tentang penyakit atau keseriusan menanggapi keluhan yang dialami pasien mempengaruhi dalam mengatasi fatigue.

\section{Hubungan status pekerjaan dengan tingkat fatigue setelah intervensi PMR}

Pada penelitian ini dihasilkan bahwa tidak ada hubungan yang bermakna antara status pekerjaan dengan tingkat fatigue dengan nilai $p \quad 0,072$, dengan rata - rata pasien adalah tidak bekerja. Status pekerjaan pada pasien yang tidak bekerja dilaporkan lebih mengalami fatigue dibanding dengan yang bekerja, hal ini dikarenakan pasien yang tidak bekerja kekurangan energi untuk melakukan pekerjaan tersebut (Liu, 2006). Menurut Guyton \& Hall (2007) orang yang kurang bergerak atau kurang beraktivitas mengakibatkan atrofi pada ototnya yang akan mencetuskan gejala fatigue, sedangkan pada orang yang banyak beraktifitas akan meningkatkan curah jantung, meningkatkan ventilasi, memperbaiki tonus otot dan mengurangi kelemahan yang akhirnya akan menurunkan gejala fatigue.

Tabel 1. Analisis perbedaan tingkat fatigue sebelum dan sesudah dilakukan intervensi pada kelompok intervensi dan kelompok kontrol di RSPAD Gatot Soebroto Jakarta $2012(\mathrm{n} 1=\mathrm{n} 2=16)$

\begin{tabular}{lccccc}
\hline Kelompok & $\begin{array}{c}\text { Me } \\
\text { an }\end{array}$ & SD & SE & $P$ & $\mathrm{n}$ \\
& & & & \\
\hline Intervensi & & & & & \\
Sebelum & 6,03 & 0,7 & 0,1 & 0,0 & 1 \\
Sesudah & 2,51 & 2 & 8 & 00 & 6 \\
& & 0,6 & 0,1 & & \\
& & 2 & 5 & & \\
\hline
\end{tabular}

\section{Kontrol}

$\begin{array}{lccccc}\text { Sebelum } & 6,13 & 0,6 & 0,1 & 0,7 & 1 \\ \text { tABWSesu } & 6,16 & 7 & 6 & 90 & 6 \\ \text { dah } & & 0,5 & 0,1 & & \\ & & 3 & 3 & & \end{array}$

Tabel 2. Analisis pengaruh karakteristik responden (usia) terhadap tingkat fatigue setelah intervensi di RSPAD Gatot Soebroto Jakarta $2012(\mathrm{n} 1=\mathrm{n} 2=16)$

\begin{tabular}{ccccc}
\hline $\begin{array}{c}\text { Variab } \\
\text { el }\end{array}$ & $\mathrm{R}$ & $\mathrm{R}^{2}$ & $\begin{array}{c}\text { Persama } \\
\text { an Garis }\end{array}$ & $P$ \\
\hline Usia & 0,38 & 0,14 & Fatigue & 0,14 \\
& 4 & 7 & $=1,414$ & 2 \\
& & & $+0,020$ & \\
& & & \\
& & & usia \\
\hline
\end{tabular}

Tabel 3. Analisis pengaruh karakteristik responden (jenis kelamin, pekerjaan) terhadap tingkat fatigue setelah intervensi di 
RSPAD Gatot Soebroto Jakarta 2012

sehari-hari pada pasien yang $(\mathrm{n} 1=\mathrm{n} 2=16)$. menjalani hemodialiasa.

\begin{tabular}{lccccc}
\hline \multicolumn{1}{c}{ Variabel } & $\begin{array}{c}\text { Mea } \\
\mathrm{n}\end{array}$ & $\mathrm{SD}$ & $\mathrm{SE}$ & $p$ & $\mathrm{~N}$ \\
\hline $\begin{array}{l}\text { Jenis kelamin } \\
\text { Laki-laki }\end{array}$ & 2,61 & 0,57 & 0,17 & 0,358 & 11 \\
Perempuan & 2,30 & 0,73 & 0,32 & & 5 \\
\hline Status pekerjaan & & & & & \\
$\begin{array}{l}\text { Bekerja } \\
\text { Tidak bekerja }\end{array}$ & 2,22 & 0,22 & 0,90 & 0,072 & 6 \\
\hline
\end{tabular}

Peran perawat dalam mengatasi

Tabel. 4 Analisis pengaruh karakteristik responden (pendidikan) terhadap tingkat fatigue setelah intervensi di RSPAD Gatot

Soebroto Jakarta $2012(\mathrm{n} 1=\mathrm{n} 2=16)$

fatigue dengan diawali pada pengkajian yang cermat tentang tingkat fatigue sehingga dapat diberikan intervensi yang tepat untuk menurunkan fatigue. Salah satu intervensi yang dapat dilakukan adalah memberikan latihan PMR untuk menurunkan fatigue pada pasien penyakit ginjal kronis yang menjalani hemodialisa sehingga PMR

\begin{tabular}{lcccc}
\hline Variabel & Mean & SD & $95 \%$ CI & $P$ \\
\hline Pendidikan & & & & \\
Tidak & & & & \\
sekolah & 0 & & & \\
SD & 3,7 & & $1,18-3,86$ & 0,146 \\
SMP & 2,52 & 0,842 & $2,15-2,91$ & \\
SMA & 2,53 & 0,453 & $1,34-2,78$ & \\
PT & 2,06 & 0,288 & $2,18-2,84$ & \\
\hline
\end{tabular}
dapat distandarisasi sebagai intervensi fatigue pada pasien khususnya pasien hemodialisa.

Penelitian ini memberikan implikasi bagi pendidikan untuk dapat memasukkan PMR sebagai terapi komplementer pada domain 1

\section{Pembahasan}

Hasil penelitian ini menunjukkan terdapat pengaruh yang signifikan antara PMR terhadap tingkat fatigue pada pasien gagal ginjal kronis yang menjalani hemodialisa. Fatigue adalah salah satu keluhan yang paling umum yang terjadi pada pasien yang menjalani hemodialisa yang dapat mempengaruhi aktivitas kehidupan psyological dengan kelas physical comfort promotion yang dapat menurunkan fatigue yang dapat melengkapi intervensi fatigue yang lain diantaranya manajemen teknik energi konservasi.

Penelitian ini dapat dijadikan data dasar dalam mengembangkan jenis intervensi keperawatan dalam 
menurunkan fatigue. Pada penelitian selanjutnya perlu dikembangkan dengan menambah jumlah sampel.

\section{Kesimpulan}

Terdapat pengaruh yang signifikan pemberian latihan $P M R$ terhadap tingkat fatigue pada pasien gagal ginjal kronis yang menjalani hemodialisa

Karakteristik pasien gagal ginjal yang menjalani hemodialisa atau variabel confounding adalah sebagai berikut, rata - rata usia pasien pada kelompok intervensi dan kelompok kontrol tidak jauh berbeda. Pada kelompok intervensi 55,06 tahun dan pada kelompok kontrol 50, 25 tahun. Sebagian besar berjenis kelamin lakilaki, pendidikan mayoritas SMA dan status pekerjaan pada kelompok intervensi sebagian besar tidak bekerja dan pada kelompok kontrol sebgaian besar bekerja.

Rata - rata tingkat fatigue pada kelompok intervensi sebelum dilakukan intervensi adalah 6,03 dan setelah intervensi 2,51. Sedangkan pada kelompok kontrol rata - rata tingkat fatigue sebelum dilakukan intervensi adalah 6,13 dan setelahnya 6,16 .

Terdapat perbedaan yang signifikan terhadap tingkat fatigue pada pasien antara sebelum dan sesudah dilakukan $P M R$.

Karakteristik pasien atau variabel confounding lainnya tidak berkontribusi dalam pelaksanaan latihan $P M R$

Berdasarkan hasil penelitian ini disarankan PMR yang merupakan Nursing Intervention Classification (NIC) dapat dijadikan panduan diruangan dalam menurunkan fatigue pada pasien gagal ginjal kronis yang menjalani hemodialisa

Dalam penelitian ini, instrument yang digunakan adalah sudah memiliki standar baku secara internasional, dengan instrument yang sudah diterjemahkan masih menjadi kendala pada responden untuk memahami pertanyaan walaupun instrument sudah dilakukan uji coba instrument. Sehingga perlu disarankan untuk penelitian selanjutnya untuk 
melakukan uji validitas bahasa dan isi, serta merevisi setiap pertanyaan terkait bahasa agar lebih mudah dipahami responden. Selain itu agar data lebih bervariasi perlu ditambahkan jumlah sampel penelitian.

\section{Daftar Pustaka}

Bonner, A.,Wellard,S.,Caltabiano. (2010). The impact of fatigue on daily activity in people with chronic kidney disease. Journal of Clinical Nursing, 19, 3006-3015

Bulecheck,G., Butcher,H., Dochterman. 2008. Nursing Interventions Classification (NIC). Fifth Edition. Philadelphia:Mosby Elsevier

Burnier, G.M., \& Graydon, J. (1993). The influence of physical activity on fatigue in patients with ESRD on haemodilysis. American Nephrology Nursing Journal, 20 (4), 457-462

Copstead, L.C., \& Banasik, J.L. (2000). Pathophysiology,

ed)Philadelphia: W.B. Saunders Company

Departemen Kesehatan Republik Indonesia. (2008). Profil Kesehatan Indonesia 2007. Jakarta

Gordon, P.L., doyle, J.W., \& Johansen, K.L. (2011). Postdialysis fatigue is associated with sedentary behavior. Clinical Nephrology, 75(5), 426-433

Greenbreg, S.S. (2002). Comprehensive stress management, $\left(7^{\text {th }} \mathrm{ed}\right)$. New York : The McGraw-Hill Companies
Guyton, A. \& Hall, J. (2007). Buku ajar fisiologi kedokteran. Jakarta : EGC

Horigan, A.,Rocchiccioli,J.,Trimm,D. (2012). Dialysis and Fatigue : Implication for Nurses - A Case study Analysis. Medical Surgical Nursing, 21, 158-175

Jablonski, A. (2007). The multidimensional characteristics of symptoms reported by patients on hemodialysis. Nephrology Nursing Journal, 34 (1), 29-37

Jhamb,M.,Weisbord,S.D.,Stell,J.L.,Unru h,M. (2008). Fatigue in patients receiving maintenance dialysis: a review of definitions, measures and contributing factors. American Journal of Kidney Disease 52, 353-365

Kwekkeboom,K.,Anderson

KA.,Wanta,B. (2010). Feasibility of patient controlled cognitive behavior intervention for pain, fatigue, and sleep disturbance in cancer. Oncolgy Nursing Forum 151-159

Liu, H.E. (2006). Fatigue and associated factors in hemodialysis patients in taiwan. Research in Nursing \& Health, 29, 40-50

Murtaugh, F., Addington-Hall, J., \& Higginson, I. (2007). The Prevelance of symptoms in end stage renal disease: A systematic review. Advances in Chronic Kidney Disease, 14(1), 82-99

McCann, K., \& Boore, J.R. (2000). Fatigue in persons with renal failure who require maintenance haemodilaysis. Journal of Advances Nursing, 32(5). 11321142

McCance, K., \& Huether, S. (2010). Pathophysiology: The biologic basis for disease in adults \& 
children ( $6^{\text {th }}$ ed.). St. Louis, MO: Mosby

McCarley, P.B., \& Arjomand, M. (2008). Mineral and Bone disorders in patients od dialysis: Physiology and clinical consequences. Nephrology Nursing Journal, 35 (1), 59-64

Mitchell,S.A.,Beck,S.L.,Hood,L.,Moore, K.,Tanmer,E.R.(2007). Putting evidence into practice : Evidence based intervention for fatigue during and following cancer and its treatment. Clinical Journal of Oncology Nursing, 11 (1), 99-113

Mollaoglu, M. (2009). Fatigue in people undergoing haemodialysis. Clinical Perspektive. Dialysis and Transplantation

NANDA Internasional. (2009). Diagnosis keperawatan : definisi dan klarifikasi 2009-2011. Jakarta : EGC

National Safety Council. (2003). Manajemen Stress. Jakarta : EGC

Nijrolder, I., Winat, D., Vries, H., Horst, D. (2009). Diagnosis during follow up of patient presenting with fatigue in primary care. Canadian Medical Association Journal, 18 (10) , 683-687

O'Sullivan, D., \& McCarthy, G. (2007). An exploration of the relationship between fatigue and physical functioning in patients with end stage renal disease receiving haemodialysis. Journal of Clinical Nursing, 16 (11c), 276-284

O’Sullivan, D., \& McCarthy, G. (2009). Exploring the symptom of fatigue in patients with end stage renal disease. Nephrology Nursing Journal. 37-47
Piper B. (1998). The revised Piper Fatigue Scale: psychometric evaluation in women withn breast cancer. Oncology Nursing Forum 25. 677-684

Polaschek, N. (2003). Living on dialysis : Concerns of clients in a renal setting. Journal of Advanced Nursing, 41 (1), 44-52

Smeltzer \& Bare. (2002). Keperawatan Medikal Bedah : Brunner \& Suddarth. Ed.8. Jakarta : EGC

Sulistini, Rumentalia. (2010). Gambaran faktor yang berhubungan dengan fatigue pada pasien yang menjalani hemodialisa di RSUP $d r$. Moh Husein Palembang. (tesis). Perpustakaan UI

Weisboard, s., Fried, L., Arnold, R., Fine, M., Levenson, D., Peterson, R., \& Switze, G. (2005). Prevelance, severity, and importance of physical and emotional symptoms in chronic hemodialysis patients. Journal of the American Society of Nephrology, 16 (8), 2487-2494

Welch JL. (2006). Symptom management. In Contemporary Nephrology Nursing: Principles and Practice (Molazhn AE \& Butera $\mathrm{E}$ eds). American Nephrology Nurse's Association, New Jersey, pp.275-292

Yildirim, Y.K., \&Fadiloglu, T. (2006). The effect progressive muscle relaxation training on anxiety level and quality of life in dyalisis patient. EDNA/ERCA Journal 